\title{
OPEN
}

Published online: 05 December 2019

\section{Author Correction: Genomewide Study of Epigenetic Biomarkers of Opioid Dependence in European- American Women}

\author{
Janitza L. Montalvo-Ortiz $\mathbb{D}^{\mathbb{D}}$, Zhongshan Cheng, Henry R. Kranzler $\mathbb{D}$, Huiping Zhang \& \\ Joel Gelernter (1)
}

Correction to: Scientific Reports https://doi.org/10.1038/s41598-019-41110-7, published online 15 March 2019

This Article contains an error in the Figure legends of Figure 3 and Figure 4 . The legends of these Figures were inadvertently switched.

The legend of Figure 3:

"Association between genotype data at rs2611513 and DNA methylation levels at GWS CpG site cg17426237. rs2611513 associated with DNA methylation levels at cg17426237; C allele associated with lower DNA methylation in (A) all sample $(n=141, p=0.025)$, and (B) OD cases $(n=112 ; p=0.042)$. No association was obtained in (C) opioid-exposed controls ( $n=29$; NS). "Represents $p<0.05$."

should read:

"Association between genome-wide significant (GWS) CpG sites and opioid dependence (OD)-related traits. DNA methylation (beta values) of GWS CpG sites associated with OD-related traits are shown: (A-C) OD symptoms, (D-F) age of onset (years), (G-I) duration of opioid use (years), (J-L) longest duration of chronic opioid use (years). Significant threshold is set at $p<0.05$."

The legend of Figure 4:

"Association between genome-wide significant (GWS) CpG sites and opioid dependence (OD)-related traits. DNA methylation (beta values) of GWS CpG sites associated with OD-related traits are shown: (A-C) OD symptoms, (D-F) age of onset (years), (G-I) duration of opioid use (years), (J-L) longest duration of chronic opioid use (years). Significant threshold is set at $p<0.05$."

should read:

"Association between genotype data at rs2611513 and DNA methylation levels at GWS CpG site cg17426237. rs2611513 associated with DNA methylation levels at cg17426237; C allele associated with lower DNA methylation in (A) all sample $(n=141, p=0.025)$, and (B) OD cases $(n=112 ; p=0.042)$. No association was obtained in (C) opioid-exposed controls $(n=29$; NS). *Represents $p<0.05$." 
(c) (i) Open Access This article is licensed under a Creative Commons Attribution 4.0 International License, which permits use, sharing, adaptation, distribution and reproduction in any medium or format, as long as you give appropriate credit to the original author(s) and the source, provide a link to the Creative Commons license, and indicate if changes were made. The images or other third party material in this article are included in the article's Creative Commons license, unless indicated otherwise in a credit line to the material. If material is not included in the article's Creative Commons license and your intended use is not permitted by statutory regulation or exceeds the permitted use, you will need to obtain permission directly from the copyright holder. To view a copy of this license, visit http://creativecommons.org/licenses/by/4.0/.

(C) The Author(s) 2019 